\title{
Vestens arvesynd
}

\section{Henrik Døcker}

\section{Hvilke motiver og hvilke kræfter, der 'styrer' eller ligger bag den politiske udvikling i de enkelte lan- de og i deres indbyrdes forhold, illustreres i to vidt forskellige bøger}

Jean Ziegler: Der Hass auf den Westen, 288 sider, C. Bertelsmann (München).

Misha Glenny: McMafia - Kriminalitet på tværs af grænserne, 472 sider, Gyldendal.

Efter at Jerntæppet gik op omkring. 1990, og verden sagde farvel til bipolariteten, har en del tidligere diktaturer efterspurgt ekspertise for at få indført vestligt prægede begreber som demokrati og respekt for menneskerettighederne. Når Vesten ikke desto mindre er vældig upopulær i store dele af verden, så skyldes det ifølge den schweiziske sociologiprofessor Jean Ziegler først og fremmest 'efterbyrden' fra kolonialismens tid. Og her troede en anden én, at hadet først og fremmest trivedes i muslimske lande, der som helhed forkaster Vestens værdisæt! Men dem nævner denne forfatter nærmest kun i en bisætning.
Som 'modgift' mod denne hvad jeg vil kalde traditionelle europæiske flagellantisme, altså påtagelse af skylden fra de kolonialistiske forfædre, kan man passende læse den britiske journalist Misha Glennys afdækning af organiseret kriminalitet bag vældig mange af nutidens politiske beslutninger, ja krige. Der er kort sagt meget mere samspil mellem verdens politiske magtudøvere og den kriminelle underverden, end man umiddelbart skulle tro. Glenny, der har bl.a. arbejdet for det britiske dagblad Guardian og BBC, har rejst i det meste af verden og har foretaget 300 interviews med politifolk, lejesoldater, mafiabosser og jurister foruden ofre for den organiserede kriminalitet.

\section{Professor, politiker, propagandist}

Men nu først Ziegler, der nylig har offentliggjort sin bog (oprindelig 


\section{LITTERATUR}

udgave dog på fransk La Haine de l'Occident) i sit 75. år og ved sin afsked fra Geneves Universitet. Som socialist og tidligere medlem af det schweiziske forbundsparlament samt forfatter til et utal af bøger (heriblandt La Suisse lave plus blanc (1990), Une Suisse au-dessus de tout soupcon - dansk udgave Schweiz - medaljens bagside (1976), L'empire de la honte (2005)) har han i årevis været kendt for sin venstreorientering, men også som engageret FN-ekspert, senest generalsekretærens særlige rådgiver vedrørende retten til mad og som medlem af det særlige rådgiverpanel for FN's Menneskerettighedsråd.

Ziegler har sammensat sin bog som en blanding af et agitatorisk skrift med diverse bevingede citater til cementering af sin opfattelse af Vesten som den store synder, hvis udbytning af sine tidligere kolonier på ingen måde kan sones, og så journalistisk-forfattede glimt fra nogle tredjeverdens lande, han har besøgt: Bolivia, Nigeria, Haiti. Nogen dybere analyse eller gengivelse af samtaler med ledende politikere fra disse eller andre udviklingslande bydes der ikke på. Men han ser 11 . september-attentaterne 2001 i New York og Washington som eksempel på 'det monstrøse had', uanset at det helt store flertal af selvmordsattentatmændene kom fra Saudi-Arabien, et land, der ikke blev koloniseret! Nuvel, deres had betegner han som patologisk had, altså - om man så må sige - undtagelsen, der bekræfter reglen: At nutidens had generelt bunder i akkumuleret had fra koloniundertrykkelsens tid.

\section{Vestens eksportstøtte til egne varer}

Man kan da godt med Ziegler lige memorere, at slavehandelen var et mørkt kapitel af kolonialismens mange rædsler, og tænke over, at over, at 40 mio. afrikanere, mænd, kvinder og børn, fra det 16 . til det 19. århundrede blev fjernet fra deres familier og deporteret til 'Den Nye Verden', til Amerika, hvor de blev pint og plaget på plantager og $\mathrm{i}$ miner, hvor de led af sygdomme og sult, hvorunder en del bukkede under. Eller at dominikanermunken, siden hen biskop Bartolomé de Las Casas så tidligt som i 1550 forfægtede, at indianerne (i Brasilien) var mennesker som europæerne, og at han væmmedes ved de afskyelige måder de blev dræbt på (uden at det dog umiddelbart reducerede spaniernes grusomheder). Det er bare ikke nyt.

$\mathrm{Nu}$ omkring 50 år efter en mængde koloniers frigørelse i Afrika, Asien og Sydamerika kan man med rimelighed kritisere megen af EU's og USA's udstrakte støtte, herunder til eksportvarer fra egne bønder, på bekostning af udviklingslandenes bønder, af Ziegler kaldet Vestens agrardumpingpolitik.

Denne politik betyder ifølge Ziegler, at fjerkræ, frugt og grøntsager i 
visse afrikanske lande kan sælges en tredjedel billigere, end de lokale kan sælge til. Det er katastrofalt, eftersom 37 ud af 53 afrikanske lande er rene landbrugslande. Det forekommer mig dog, at forfatteren ikke tager tilstrækkelig hensyn til, hvad en egentlig frihandel vil medføre for Europas og Nordamerikas bønder, der også er trængt. Hertil kommer, at Kina, Indien og Brasilien ikke vil fjerne deres høje toldmure. Ziegler understøtter bestandig sine standpunkter med citater af ulandspolitikere eller personlige indtryk fra sine rejser bl.a. i FN's tjeneste.

Sceneskift til Frankrig og dets bevares efterhånden mere og mere upopulære - præsident Nicolas Sarkozy, der på 'demagogisk' vis maner afrikanske bønder til at blive selvforsørgende. Så kastes et tilbageblik på Algeriet i 1950'er og 60'erne, og den befrielseskrig, som ifølge Ziegler kostede næsten fem mio. mennesker livet. Algeriets aktuelle problemer med muslimsk-funderet voldelig ekstremisme forekommer mig alvorligere end Sarkozys verbaldueller med hans algeriske præsidentkollega Abdelaziz Bouteflika om, hvorvidt Frankrig skal undskylde fortidens koloniale synder, herunder ofrene for uafhængighedskrigen.

\section{Blodige træfninger}

Hans beskrivelser fra Nigeria vejer tungere. Dette mægtige land, der med sine 137 mio. indbyggere er Af- rikas mest folkerige, skylder gas og olie 90 pct. af sin rigdom, men staten er svag, fordi den er i lommen på olieselskaberne. 27 mio. nigerianere bor i Niger-flodens vældige, 70.000 kvadratkilometer store delta og lider under de store olieselskabers, særlig Shells virksomhed. Den udstrømmende gas bringer gifte med sig, som imidlertid afbrændes fra høje skorstene. Ifølge amerikanske forskere strømmer der mere $\mathrm{CO}_{2}$ ud fra deltaets oliefelter end fra alle oliefelter i hele verden.

Der raser i deltaet en yderst blodig, men i omverdenen lidet påagtet krig. Det er Befrielsesbevægelsen for Nigerdeltaet - MEND - med mere end 1000 mand under våben, og som råder over gummibåde, geværer, granatkastere miner m.m., der forøver attentater mod de udenlandske olieselskabers anlæg, fx det italienske Agips. De er også gået til angreb på en af Shells boreøer, hvis platforme blev sprængt i luften. Sabotageaktionerne skulle have påført den nigerianske statskasse et dagligt tab på 39 mio. euro.

Zieglers helt store helt er den bolivianske præsident Ivo Morales, den første indianer, der på demokratisk vis er blevet valgt til det højeste embede i nogen latinamerikansk republik. Just genvalgt i december 2009 står han stærkt efter nationaliseringer af fremmede olieselskaber og over for også at lade jernbanerne blive statslige. Morales, selv fagforeningsmand, er indbegrebet af en 


\section{LITTERATUR}

tredjeverdens-politiker, som har brudt helt med det kapitalistiske Vesten, og som sågar udpeger den herostratisk berømte revolutionære guerillaleder Che Guevara (192867) som ét af sine idoler - oprindelig den cubanske diktator Fidel Castros medspiller, men siden hen oprørsleder i forskellige latinamerikanske lande inden sin død i kamp med militæret netop i Bolivia. Ziegler dvæler med rette ved Bolivias nye forfatning af 2007, som har hele 431 paragraffer, hvoraf de 33 vedrører beskyttelsen af menneskerettighederne.

\section{En tredjedel af verden lever i nød}

For verdens fattige har verdensmarkedsprisernes stigning - ifølge FN's særorganisation for levnedsmidler og landbrug FAO med 50 pct. i tidsrummet 2003-09 - haft katastrofale følger. Tre såkaldte strategier er skyld i, at Vesten har udløst denne stigning: Den Internationale Valutafonds krav til 122 udviklingslande om gennem strukturtilpasningsforanstaltninger at få nedbragt noget af deres samlede gæld på 2,1 milliarder dollar - og kun ved eksport af især bomuld, soja, rørsukker, palmeolie, kaffe og kakao kan de skaffe sig fremmed valuta. Det tvinger så $\mathrm{i}$ vekslende forhold disse lande til at importere levnedsmidler, undertiden op til en tredjedel af deres behov.

Så er der også spekulation. Chef- økonom ved FN's stående Konference for Handel og Udvikling (UNCTAD) Heiner Flassbäck anslår, at spekulationsgevinsternes andel i næringsmidlernes pris-himmelflugt når op på 50-60 pct. Præsidenten for Verdensbanken Robert Zoellnick skyder på 37 pct.

Den tredje grund til priseksplosionen er omformningen af i hundredevis af millioner tons majs og korn (palmeolie mv.) til bioethanol og biodiesel. Af dette er USA den største producent. Præsidenterne George Bush og Barack Obama retfærdiggør denne offentligt subventionerede produktion fra store amerikanske 'agrar-koncerner' med at den nedsætter forureningen og USA's afhængighed af olie. Det lyder plausibelt, men ved nærmere studium udgør det iflg. Ziegler intet mindre end en forbrydelse mod menneskeheden. Lyt: For at fylde en 50 liters tank i en mellemklassebil med bioethanol, skal der afbrændes $358 \mathrm{~kg}$ majs. Dette kvantum kan holde et barn i Mexico eller Zambia, hvor majs er det basale næringsmiddel, i live i et år.

Den historisk og økonomisk velbevandrede forfatter har mange andre regnestykker, som kan få én til at gyse, og måske ind imellem tvivle. Men det maner til eftertanke, at over 2,2 mia. mennesker, en tredjedel af verdens befolkning, lider af permanent underernæring, mangel på medicin eller drikkevand. Men disse uheldsvangsvangre faktorer 
kan dog nok ikke umiddelbart sammenkobles med kolonialismens efterbyrd - og så hører vi stort set ingenting om den megen ulandsbistand, som trods alt formidles verden over.

\section{Gangstervælde}

Nuvel, Glennys bog har strengt taget intet med Zieglers emne at gøre, men den kan læses som et slags supplement gennem dens nyttige afdækning af en lang række faktorer, menigmand ikke kender til i detaljen. Han påpeger bl.a., at globaliseringen med dens liberalisering af finans- og varemarkeder sammen med kommunismens fald har styrket hvad han kalder skyggeøkonomien, som ifølge Verdensbanken og forskningsinstitutter i Europa og USA skønnes at stå for $15-20$ pct. af den totale omsætning af varer. Opløsningen af Sovjetunionen skabte iflg. Glenny 'verdens største tyveri', kort fortalt ved salg af statsforetagender til en udvalgt kreds til latterligt lave beløb.

En slags gansterimperialisme udvikledes ved rigtig mange sovjet-jøders udvandring til Israel, jøder, der ofte var blevet diskrimineret under det kommunistiske regime, og som nu fik åbnet en port til verden - for deres mere eller mindre lyssky forretninger. Israelsk politi skønner, at disse russere siden kommunismens fald har fået hvidvasket mellem fem og ti milliarder dollar i israelske banker.

Mens Valutafonden tilførte Rusland milliarder af dollars for at stabilisere økonomien, sendte det russiske oligarki endnu større summer til obskure banker verden over i rent spekulationsøjemed.

Man kan supplere Zieglers mistrøstige Nigeria-beskrivelse med Glenny, der går så vidt som til at betegne olieselskabernes position som så stærk, at de nærmest har 'privatiseret' Nationalbanken. En lille elite af befolkningen er stenrige, men fra 1995 til 2006 faldt gennemsnitsalderen fra 54 til 43 år. Mens Ziegler gerne vil fokusere på de grumme kapitaliststater fra 'den gamle verden', som roden til megen af verdens nutidige ulighed og almindelige misère, så kan Glenny pege på en anden 'historie' om store, mere eller mindre internationale, forbrydersyndikater, som - ikke mindst gennem international narkohandel - har deres skyld i menneskelig elendighed og ufattelige sociale uligheder.

Men at hadet til Vesten i meget vidt omfang trives mest intenst i fundamentalistiske muslimske kredse optager altså ikke den gamle socialist Jean Ziegler.

Henrik Døcker er journalist og forfatter med speciale i menneskerettigheder. 